20. МТОТ презентувало проект Стратегії інтеграції внутрішньо переміщених осіб та впровадження довгострокових рішень щодо внутрішнього переміщення на період до 2020 року. URL: http://mtot.gov.ua/mtot-prezentuvalo-proekt-strategiyi-integratsiyi-vnutrishno-peremishhenyh-osib-ta-vp rovadzhennya-dovgostrokovyh-rishen-shhodo-vnutrishnogo-peremishhennya-na-period-do-2020-roku/.

21. Про схвалення Стратегії інтеграції внутрішньо переміщених осіб та впровадження довгострокових рішень щодо внутрішнього переміщення на період до 2020 року: Розпорядження Кабінету Міністрів України від 15 листопада 2017 р. № 909-р. Офіційний вісник України. 2017. № 102. Ст. 3157.

22. Про житловий фонд соціального призначення: Закон України від 12 січня 2006 р. № 3334-IV. Офіиійний вісник Украӥни. 2006. № 5. Ст. 208. (Із змінами).

23. Деякі питання реалізації Закону України «Про житловий фонд соціального призначення»: Постанова Кабінету Міністрів України від 23 липня 2008 р. № 682. Офіиійний вісник України. 2008. № 56. Ст. 1885.

24. Про тимчасові заходи на період проведення антитерористичної операції: Закон України від 2 вересня 2014 р. № 1669-VII. Відомості Верховної Ради Украӥни. 2014. № 44. Ст. 2040. (Із змінами).

25. Про затвердження Положення про Міністерство 3 питань тимчасово окупованих територій та внутрішньо переміщених осіб України: Постанова Кабінету Міністрів України від 8 червня 2016 р. № 376. Офіційний вісник Украӥни. 2016. № 51. Ст. 1802.

26. Про затвердження Положення про Міністерство соціальної політики України: Постанова Кабінету Міністрів України від 17 червня 2015 р. № 423. Офіиійний вісник України. 2015. № 51. Ст. 1655.

УДК 349.2

Л. П. Амелічева доцент кафедри цивільного права і процесу Донецького національного університету імені Василя Стуса, канд. юрид. наук, доцент

О. В. Нефьодов студент юридичного факультету Донецького національного університету імені Василя Стуса

\title{
ПРЕКАРІЗАЦІЯ ЯК ЧИННИК ТРАНСФОРМАЦІЇ ІНСТИТУТУ ТРУДОВОГО ПРАВА «ЗАЙНЯТІСТЬ І ПРАЦЕВЛАШТУВАННЯ» В УМОВАХ ДЕФІЦИТУ ГІДНОЇ ПРАЦІ
}

Ключові слова: зайнятість, прачевлаштування, прекарізаиія, гідна прачя, нестандартні види зайнятості, дистанційна зайнятість, робота вдома, позикова праия, робота на умовах неповного робочого часу або неповної зайнятості, строкова зайнятість та короткострокова зайнятість.

В Україні останнім часом за допомогою емпіричних методів пізнання проведені грунтовні соціально-економічні дослідження щодо структурних змін 
такого феномену як зайнятість населення в умовах дефіциту гідної праці $[1 ; 2$; 3]. Вчені одностайні в тому, що в Україні перехід від індустріальної до постіндустріальної фази економічного розвитку супроводжується становленням постфордистької моделі зайнятості, ознакою якої є прекарізація - процес трансформації стандартних трудових відносин в їх нестандартні й нестабільні форми в умовах високого рівня тінізації сфери праці.

Нині, вочевидь, є загроза, що через відносну слабкість профспілок й рішучу налаштованість правлячої еліти на продовження неоліберального курсу прийняття нового Трудового кодексу буде сприяти стрімкому розповсюдженню вже легальних видів нестандартної зайнятості, що буде вигідно, в першу чергу, роботодавцям [2, с. 1$]$.

Як вбачається, щодо актуалізованих на сьогодні проблемних питань трансформації інституту трудового права «зайнятість і працевлаштування» представники науки трудового права повинні «бити в набат», стати рушійною силою в сучасному (трудо)правоутворенні, а саме, активно співпрацювати із законодавцем під час розробки нових норм проекту Трудового кодексу України, в яких слід передбачати дієві засоби протидії деяким негативним проявам прекарізації саме як засоби «традиційного» трудового права, виходячи із поглядів на його історичний (передусім захисний) смисл [4, с. 111]. Науковцямправознавцям необхідно використовувати будь-яку можливість обговорення дієвості й відстоювання значущості цих норм або в спеціальній юридичній літературі, або шляхом участі в тематичних науково-практичних конференціях, під час підготовки експертної оцінки законопроекту й ін.

Питання правового регулювання зайнятості як компоненти гідної праці, окремих нестандартних видів зайнятості висвітлювалися у наукових працях С. В. Венедиктова [5], С. В. Вишновецької [6], В. В. Жернакова [7], М. І. Іншина [8], І. В. Лагутіної [9], П. Д. Пилипенка [10], С. М. Прилипка [11], О. І. Процевського [12], Г. І. Чанишевої [13], О. М. Ярошенка [14] й ін. Розвиток інституту гідної праці зазначені вчені безпосередньо пов'язують зі створенням можливостей зайнятості, з вільною, повною та продуктивною працею, з ії̈ безпекою та рівністю на роботі, соціальним захистом і активізацією соціального діалогу. Можливості гідної зайнятості - це перш за все, - збільшення масштабів формальної економіки, це офіційне працевлаштування за дотримання вимог, які $\epsilon$ не взаємозамінними, а виключно взаємодоповнюючими. Механізми ж функціонування неформальної економіки (правові, економічні, інституціональні, морально-етичні тощо) є такими, що формують і постійно відтворюють умови, за яких одночасна наявність усіх ознак гідної праці є неможливою [3, с. 19]. Не применшуючи цінності наукових праць вказаних вчених, слід зауважити, що значна кількість проблем у зазначеній сфері залишається невирішеною i потребує грунтовного дослідження 3 урахуванням стрімкого розповсюдження нестандартних видів зайнятості в Україні в умовах дефіциту гідної праці.

Вищенаведене обумовлює актуальність теми цієї статті.

Метою дослідження є узагальнення положень щодо основних нестандартних видів зайнятості, в яких проявлясться прекарізачія, $i$ визначення 
напрямів розвитку інституту трудового права «зайнятість $і$ працевлаштування» у контексті протидії деяким негативним проявам прекарізації в умовах дефіuзиту гідної праціi.

Прекарізація як явище й поняття нове у трудовому праві, малодосліджене. Проте, вченими-соціологами й економістами проводилися грунтовні дослідження щодо його змістовного наповнення. Так, в спеціальній літературі прекарізація визначається як тенденція розвитку соціально-трудових відносин сучасного суспільства, що передбачає перехід від класичних трудових договорів (контрактів) до таких форм найму, за яких все більша кількість людей вимушена самостійно будувати свою трудову стратегію в умовах нестабільності й відсутності гарантій зайнятості, що збільшує їх економічну й соціальну вразливість, сприяє втраті професійної ідентичності й сходженню у нижчі прошарки суспільства [15, с. 35].

Слід зауважити, що явище прекарізації має глобальний характер, не обходить і розвинуті країни. У сучасному світі масштаби і значення прекарізації безупинно зростають. Відповідно, це свідчить про те, що дедалі росте попит на нестандартні види зайнятості 3 боку роботодавців i, як наслідок, трансформується пропозиція праці. Тобто, в таких умовах вже некорректно стверджувати, що стандартна зайнятість в ідеалі має бути єдиною у соціальнотрудових відносинах.

Прекарізація проявляється у таких нестандартних видах зайнятості, як:

дистанційна зайнятість або віддалена робота (telework, e-work);

робота вдома (work at home);

позикова праця (borrowed employee);

зайнятість на основі договорів цивільно-правового характеру (employment on the basis of civil law contracts) та псевдопідприємництво (pseudo-selfemploument) або підпорядкована індивідуальна трудова діяльність (dependentself-emploument);

незареєстрована зайнятість у формальному секторі (unregistered employment in the formalsector);

строкова зайнятість (fixed-term);

робота на умовах неповного робочого часу або неповної зайнятості (parttimework) [16, с. 94; 17, с. 297] й ін.

Базуючись на зазначеній класифікації нестандартних видів зайнятості, надалі слід вказати основні суттєві ознаки кожного з таких видів та визначити напрями розвитку інституту трудового права «зайнятість і працевлаштування», безпосередньо пов'язані з поширенням цих видів зайнятості на виробництві.

1. Дистанційна зайнятість або віддалена робота (telework, e-work).

Процеси глобалізації, науково-технічна революція, розвиток інформаційних технологій та засобів масової комунікації безпосередньо впливають на характер суспільно-трудових відносин. Завдяки засобам зв'язку та мережі Інтернет змінилася організація праці на підприємствах, установах, організаціях. Нині на виробництві стало розповсюджуватися таке явище, як дистанційна 
зайнятість або дистанційна праця, яка вперше була запроваджена Каліфорнійськими бізнес-компаніями, такими як Үahoo, ще в 1980-х роках [18, с. 2].

Як зазначає Н. М. Вапнярчук, дана форма зайнятості підвищує доступність праці для багатьох категорій населення (пенсіонерів, інвалідів, вагітних жінок, тощо), усуває географічні труднощі (завдяки мережі Інтернет та іншим засобам зв'язку), знижує соціальну напругу. Більше того, працівник особисто може формувати свій робочий день, виконувати трудову функцію в зручних для нього умовах, що позитивно відображається на його продуктивності та ефективності. Щодо роботодавця, то його користь полягає в мінімізації витрат на утримання персоналу, оренду офісного приміщення, оплату комунальних послуг, закупівлі необхідного облаштування й ін. [19, с. 101].

На жаль, на сьогодні вітчизняне законодавство, в першу чергу, чинний Кодекс законів про працю України (далі - КЗпП України) взагалі не містить норм, які б розкривали зміст поняття «дистанційна зайнятість», забезпечували правове регулювання відповідних відносин та визначали статус працівників, задіяних у цій сфері. В розвинутих країнах СС, зокрема в Польщі, визначення такого виду зайнятості під терміном «телепраця» (трудова діяльність, яка може провадитися зовні приміщення роботодавця на регулярній основі з використанням засобів електронного зв'язку) та процесів, пов'язаних з нею, були закріплені на рівні законодавства (зокрема, в Трудовому кодексі Польщі ще у 2007 році) [20, с. 1-2]. У ст. 32 проекту Трудового кодексу України вказано, що «умови трудового договору можуть передбачати виконання працівником роботи дистанційно (поза приміщенням роботодавця), у тому числі з можливістю віддаленого доступу за допомогою інформаційно-комунікаційних технологій» [21], однак детального правового регулювання та організації цього виду зайнятості у зазначеному проекті не передбачено.

2. Робота вдома (work at home).

На сьогодні цей вид нестандартної зайнятості регулюється Положенням про умови праці надомників від 29.09.1981, в якому передбачається, що переважне право на укладення трудового договору щодо праці на дому надається: жінкам з дітьми у віці до 15 років, особам з інвалідністю та пенсіонерам, особам, що досягли пенсійного віку, особам із зниженою працездатністю, яким в установленому порядку рекомендована праця в домашніх умовах, особам які доглядають за інвалідами або хворими членами сім'ї, що потребують догляду, тощо. Як вбачається, за зазначеним документом дистанційно зайняті працівники та надомні працівники практично нічим не відрізняються, на перший погляд. Проте, Я. В. Свічкарьова слушно зауважує, що розмежування надомної праці і телероботи слід проводити за трьома критеріями: 1) за змістом: якщо телеробота носить переважно інтелектуальний характер, іiі результатом, як правило, $\epsilon$ якийсь «програмний продукт», то надомна праця цього обов'язково не припускає; 2) за способом виконання: при телероботі обов'язково використовуються індивідуальні засоби зв'язку і телекомунікацій, при надомній праці це не передбачається; 3) за місцем виконання (розташуванням робочого місця): працівники-надомники виконують роботу тільки у своєму житловому примі- 
щенні, а телепрацівники - поза офісом без прив'язки саме до свого житла [22, c. 140]. Крім того, основна відмінність цих понять полягає ще в тому, що надомні працівники фактично змушені виконувати роботу, передбачену трудовим договором, поза приміщенням роботодавця в домашніх умовах у зв'язку з неможливістю іï виконання за розташуванням робочого місця через соціальні та/або фізичні причини, тоді як телепрацівники виконують роботу за власним бажанням та можливістю їі виконання не лише вдома, але й в сучасних коворкінгах 3 метою оптимізації власного робочого часу та продуктивності праці, якщо вдома ії виконанню заважають члени сім’ї.

В спеціальній юридичній літературі висловлюється думка про осучаснення чинного Положення про умови праці надомників, в якому слід було б передбачити письмову форму укладення трудового договору, де б закріплювалися конкретні трудові гарантії надомних працівників[23; 24, с. 68] й ін.

3. Позикова праця (borrowed employee).

Позикова праця проявляється в таких нестандартних видах зайнятості (або видах нетипової трудової діяльності), як: аутсорсинг - передання окремих (непрофільних) функцій підприємства зовнішній компанії (аутсорсеру), яка є спеціалістом у цій галузі, для обслуговування на тривалий строк; аутстафінг виведення працівників зі штату роботодавця-користувача i оформлення їх у штат іншого роботодавця (провайдера), при цьому працівники залишаються працювати на попередньому робочому місці і виконувати попередні обов'язки, а обов'язки роботодавця стосовно них виконує вже провайдер (приватне агентство зайнятості, кадрове агентство) [25, с. 178]; лізинг персоналу - тимчасове залучення працівників відповідної кваліфікації та профілю до виконання певних видів завдань (проектів) іншої компанії (фактичного роботодавця) [26, с. 179].

Досліджуючи позикову працю, варто зазначити, що на противагу постійній зайнятості, яка грунтується на стандартних трудових правовідносинах i передбачає, що будь-який працівник повинен найматися безпосередньо роботодавцем на невизначений строк, указані види нетипової трудової діяльності належать до зайнятості нестандартної (непостійної, нестійкої) [25, с. 151]. Використання цих нестандартних видів зайнятості роботодавцем та залучення позикових працівників пояснюється такими перевагами: 1) підприємства у разі необхідності можуть швидко замінювати працівників, які відсутні 3 тих чи інших причин (відпустка, відрядження, хвороба тощо); 2) запозичення дозволяє мати роботодавцю потрібну кількість працівників для оперативного виконання виробничих завдань (термінових, непередбачуваних, пов'язаних із сезонністю тощо); 3) запозичення персоналу на умовах, узгоджених з агентством зайнятості, дозволяє у багатьох випадках оптимізувати витрати на персонал $[27$, с. 30] й ін.

Однак, на становище працівників такий нестандартний вид зайнятості впливає у більшій мірі негативно, а саме, погіршує його порівняно із законодавством про працю. Так, профспілки України, зокрема, профспілка металургів і гірників України, наголошують, що працівники, зайняті на умовах позикової праці, мають гірші умови праці, зокрема нижчу заробітну плату, ніж основні працівники. До недоліків позикової праці також можна віднести такі: 
1) позикові працівники позбавлені гарантії постійної зайнятості, оскільки в будь-який момент, незалежно від якості виконаної ними роботи, можуть бути переведені на інше підприємство або звільнені; 2) тимчасовий характер праці позбавляє позикових працівників багатьох винагород, що пов'язані з тривалістю роботи на одному місці, наприклад, виплат за стаж, соціальне страхування та інше $[27$, с. 30].

Як слушно зауважує І. В. Лагутіна, позикова праця викликає зростання нерівності та соціальної незахищеності [28, с. 156], тому в ст. 39 Закону України «Про зайнятість населення» необхідно детально регламентувати вказані різновиди позикової праці, щоб роботодавці максимально дотримувалися вимог трудового законодавства й не уникали відповідальності за їх порушення.

4. Зайнятість на основі договорів цивільно-правового характеру (employment on the basis of civil law contracts) та псевдопідприємництво (pseudoself-emploument) або підпорядкована індивідуальна трудова діяльність (dependent-self-emploument).

Варто зауважити, що у науці трудового права до нестандарного виду зайнятості, заснованого на договорах про працю цивільно-правового характеру, сформувалося переважно негативне ставлення $[5$, с. $53 ; 29$, с. 236]. Адже, за формально-юридичними ознаками такі договори неможливо чітко визначити ні як трудовий договір (контракт) за нормами КЗПП України, ні як договір підряду чи договір про надання послуг або авторський договір за нормами ЦК України. Так, Л. О. Сироватська слушно висловлює думку, що «в реальному житті все частіше і частіше укладають якісь трудові угоди, які слід було б назвати навіть не гібридами, але мутантами-виродками, що народжуються від схрещування трудових і цивільно-правових норм» [30, с. 82].

Недоліки зайнятості на основі договорів про працю цивільно-правового характеру проявляються у тому, що працюючому не зараховується в страховий стаж, у тому числі, пільговий, час роботи, він немає права на відпустку, на пільгову пенсію, оплату страхових виплат у разі втрати непрацездатності, нещасного випадку на виробництві й на безліч інших трудових гарантій. Отже, в реальній дійсності такі «розмиті» договори дозволяють роботодавцю зняти 3 себе усіляку трудоправову відповідальність у відносинах із працюючим.

Однак, серед представників науки трудового права $\epsilon$ i прихильники застосування таких договорів [31, с. 116], адже в деяких випадках, коли фізична особа хоче заробити більше грошей, проте вона вже задіяна як основний працівник на підприємстві, то укладення таких договорів $є$ для неї бажаним та прийнятним.

Отже, як вбачається, повністю заборонити використання такого виду нетипової трудової діяльності (прихованої зайнятості) сьогодні практично неможливо, тому нині необхідно доповнити як чинний КЗпП України, так $\mathrm{i}$ проект Трудового кодексу України нормами-заборонами щодо укладення зазначених договорів на небезпечних роботах, в агропромисловому комплексі та будівництві, де є підвищений ризик або отримати виробничу травму, або 
поступово погіршити стан здоров'я під впливом небезпечних виробничих факторів [2, с. 55].

Щодо такого нестандартного виду зайнятості як трудова діяльність у статусі фізичної особи-підприємця, що здійснюється на підставі цивільноправового договору про виконання певної роботи для замовника (фактичного роботодавця) 3 обов'язковим дотриманням прямих його вказівок та отриманням за це винагороди, слід зазначити наступне. Умови праці за вказаним договором не регулюються положеннями трудового законодавства, а самі працюючі особи позбавлені основних ключових трудових прав (право на об'єднання для ведення колективних переговорів, право на належні, безпечні і здорові умови праці, право на оплату праці, не нижче встановленого державою мінімуму й ін.). Зазначені умови праці в певній мірі стирають межі між фізичною особоюпідприємцем та працівником, 3 одним тільки винятком - фізична особапідприємець здійснює свою трудову діяльність на власний ризик, сприймаючи можливість настання негативних економічних наслідків, зумовлених такою діяльністю. Цей нетиповий вид трудової діяльності є вигідним, насамперед, для роботодавця, який примушуючи виконавця робіт (фактичного працівника) до оформлення статусу фізичної особи-підприємця, мінімізує виплату податків й страхових внесків за використану працю. Тобто, характерною ознакою вказаного нестандартного виду зайнятості $€$ фінансова та персональна залежність фізичної особи-підприємця від замовника на підставі цивільно-правового договору про виконання певної роботи [5, с. 53]. Саме такий за ознаками нестандартний вид зайнятості в спеціальній літературі отримав назву «псевдопідприємництво» [2, с. 52] («підпорядкована індивідуальна трудова діяльність» $[5$, с. 53] чи «псевдо-самозайнятість» [6, с. 3]). Як вбачається, цей нестандартний вид зайнятості також погіршує правове становище працюючих порівняно із законодавством про працю.

Тому варто в чинному КЗпП України і в проекті Трудового кодексу України передбачити норми-заборони щодо використання праці за зазначеним вище нестандартним видом зайнятості. У разі виявлення застосування роботодавцем вказаного нестандартного виду зайнятості - його слід притягнути до відповідальності як при виявленні фактичного допуску працівника до роботи без оформлення трудового договору (контракту) відповідно до ст. 265 КЗпП України (відповідно до ст. 362 проекту Трудового кодексу України).

5. Незареєстрована зайнятість у формальному секторі (тіньова зайнятість) [2, c. 43] (unregistered employment in the formalsector).

У 2015 році в Україні частка сегменту незареєстрованої зайнятості досягла приблизно 26,4% від усього зайнятого населення [32, с. 20]. Приблизно половина неоформлених працівників була зайнята у формальному секторі. Зрозуміло, що ціна усних домовленостей у сфері праці робить працівника повністю незахищеним перед роботодавцем, він відчуває себе принизливо, якщо виконує таку саму роботу разом із працівником, що офіційно оформлений і на якого розповсюджуються всі трудові гарантії за законодавством про працю. Така зайнятість 
завдає шкоди інтересам працівників, $€$ зловживанням 3 боку роботодавців, сприяє створенню дефіциту гідної праці, і не повинна мати місце [33, с. 124].

3 метою зменшення масштабів тіньової зайнятості можна запропонувати доповнити ст. 29 чинного КЗпП України і ст. 56 проекту Трудового кодексу України нормою, яка б передбачала введення нового обов'язку для роботодавця - видавати всім працівникам документ (посвідчення) на паперовому носії або картку з електронним чипом, що засвідчує їх приналежність до відповідного роботодавця. Зазначене дозволить більш результативніше проводити перевірки роботодавців інспекторами Держпраці на предмет виявлення осіб, що працюють без офіційного працевлаштування.

6. Строкова зайнятість (fixed-term).

Строкова зайнятість $є$ досить поширеним нестандартним видом зайнятості в нашій державі. На думку С. О. Сільченко, з якою можна погодитись, існують такі види строкових трудових договорів: 1) трудовий договір, укладений на визначений строк, встановлений за погодженням сторін (п. 2 ст. 23 КЗпП України); 2) трудовий договір, що укладається на час виконання певної роботи (п. 3 ст. 23 КЗПП України); 3) трудовий договір про виконання тимчасової роботи; 4) трудовий договір про виконання сезонної роботи; 5) трудовий контракт [34, с. 9].

Класифікація строкових трудових договорів й порядок їх укладення та припинення чітко регламентуються у ст. ст. 23, 39, 391 КЗПП України й ін. Однак, у правовому регулюванні строкової зайнятості є і недоліки. По-перше, у законодавстві про працю немає чітких обмежень щодо максимальної тривалості строкових трудових договорів [5, с. 50-51]. Варто й корисно було б врахувати досвід європейських країн й доповнити ст. 23 КЗпП України нормою щодо максимальної тривалості строкових трудових договорів (як це передбачено, наприклад, у Великобританії (4 роки), в Іспанії (3 роки), Німеччині (2 роки)), попередньо визначивши прийнятну для України тривалість цих договорів через механізми соціального діалогу з метою сприяння зменшенню соціальної напруги в країні в умовах дефіциту гідної праці. По-друге, укладення строкових трудових договорів порівняно із безстроковими за законодавством надає більше переваг для роботодавця, а тому це підштовхує його до ігнорування вимог законодавства щодо обмеження укладення строкових трудових договорів. Так, звільнення працівника відбувається без виплати вихідної допомоги, згоди профспілки й $є$ допустимим в період відпустки чи хвороби працівника. Періодичне припинення трудових відносин обмежує реалізацію деяких трудових прав, пов'язаних із безперервним стажем роботи (щодо переважного права залишення на роботі при скороченні штату, щодо права йти у відпустку у перший рік роботи після закінчення шести місяців безперервної роботи й ін.). Тому законодавство 3 питань укладення строкових трудових договорів варто удосконалити у напрямі попередження зловживань правами зі сторони роботодавців. Зокрема, варто підвищити мінімальну оплату праці в 1,5 рази для строковиків, ввести заборону на їх звільнення у разі скорочення штату й ін. По-третє, у чинному КЗпП України необхідно скасувати контрактну форму 
трудового договору як штучну підставу для диференціації, адже можливість укладення контракту породжує співіснування окремих категорій працівників як на основі безстрокового, так і строкового трудового договору. До того ж контракти ще й унеможливлюють їх трансформацію в безстрокові трудові договори [34, с. 13].

7. Робота на умовах неповного робочого часу або неповної зайнятості (part-timework).

Визначення неповної зайнятості передбачено у ст. 1 Закону України «Про зайнятість населення» від 05.07.2012. Неповна зайнятість - зайнятість працівника на умовах робочого часу, що менший від норми часу, передбаченої законодавством, i може встановлюватися за договором між працівником i роботодавцем з оплатою праці пропорційно відпрацьованому часу або залежно від виробітку. Порядок встановлення неповного робочого часу, його оплати, а також загальна норма про заборону будь-яких обмежень обсягу трудових прав працівників, які працюють на умовах неповного робочого часу, передбачаються ст. ст. 32, 56, 172 КЗпП України. На думку Г. І. Чанишевої, 3 якою можна погодитись, правова регламентація неповного робочого часу у трудовому законодавстві України залишається недосконалою, адже не враховує міжнародні (Конвенція МОП № 175 про роботу на умовах неповного робочого часу 1994 року та Рекомендацію МОП № 182 про роботу на умовах неповного робочого часу 1994 року) та європейські стандарти праці (Рамкову угоду СС про роботу на умовах неповного робочого часу від 06.06.1997), тому сьогодні підвищується значення договірного регулювання цього питання [13, с. 12]. Але укладення колективного договору не є обов'язком роботодавця, тому зазначена проблема лише посилюється. Відправлення працівників у вимушені неоплачувані відпустки, псевдоскорочення робочого часу, обумовлені різким підвищенням розміру мінімальної заробітної плати в державі й фінансовими труднощами роботодавців - феномени сьогодення, які характеризуються масовістю i масштабністю через безкарність роботодавців-порушників. Адже правова культура і рівень відповідальності роботодавців, а також ефективність діяльності Держпраці через малочисельність штату й низький рівень оплати праці інспекторів на сьогодні є незадовільними. До того ж у ст. 7 Закону України «Про загальнообов'язкове державне соціальне страхування на випадок безробіття» вже не передбачена виплата допомоги по частковому безробіттю через органи Державної служби зайнятості України, хоча у ст. 47 Закону України «Про зайнятість населення» така допомога передбачається і чітко врегульований механізм їі виплати.

На сьогодні доцільно доповнити Закон України «Про зайнятість населення» нормою про обов'язок роботодавців повідомляти органи Державної служби зайнятості України про масові відправлення працівників у безоплатні відпустки, а також поновити у ст. 7 Закону України «Про загальнообов'язкове державне соціальне страхування на випадок безробіття» право на виплату допомоги по частковому безробіттю (як це передбачено у ст. 47 Закону України «Про зайнятість населення»). 
Таким чином, все вищевикладене дозволяє зробити такі висновки:

1. Явище прекарізації є об'єктивно існуючим на виробництві у різних країнах, й Україна не є винятком. Прекарізація є одним з основним чинників, щуо впливає на трансформацію інституту трудового права «зайнятість $i$ прачевлаштування» через активне розповсюдження нестандартних видів зайнятості в умовах глобалізації та дефіu̧іту гідної праџу. Такими нестандартними видами зайнятості є строкова і неповна зайнятість, дистанційна і позикова праия й ін.

2. У контексті протидї деяким негативним проявам прекарізації напрямами розвитку інституту трудового права «зайнятість і працевлаштування» $у$ сучасних умовах можуть стати, зокрема: 1) розробка норм-заборон щуодо укладення договорів про працю цивільно-правового характеру з працівниками, які задіяні на небезпечних роботах, й з фізичними особами-підприємиями у випадках «підпорядкованої індивідуальної трудової діяльності»; 2) скасування норм чинного КЗпП Украӥни, щзо передбачають контрактну форму трудового договору; 3) поновлення права на виплату допомоги по частковому безробіттю иляхом закріплення відповідної норми у ст. 7 Закону України «Про загальнообов 'язкове державне сочіальне страхування на випадок безробіття».

Наведені висновки можуть використовуватися у подальших трудоправових дослідженнях щодо удосконалення правового регулювання нестандартних видів зайнятості.

1. Новак I. М. Структурні зрушення в зайнятості населення України. Демографія та сочіальна економіка. 2015. № 3. С. 185-198.

2. Атипичная занятость и прекаризация труда в Украине / Под. ред. В. Дудина и 3. Поповича. Киев: Центр социальных и трудових исследований, 2017. 69 с. URL: http://rev.org.ua/wp-content/uploads/2017/12/Atypical-Employment_Brochure.pdf.

3. Колот А. М., Герасименко О. О. Гідна праця у дзеркалі теоретико-прикладних досліджень: сучасний концепт, причини дефіциту та стратегічні вектори його подолання. Імперативи та інноваційні механізми забезпечення гідної прачі в умовах становлення нової економіки: зб. тез доп. учас. Міжнар. наук.-практ. конф. Київ, 25-26 квіт. 2017 р. С. 17-24.

4. Панасюк О. Т. Зайнятість як фактор сучасного (трудо)правоутворення. Правові, економічні та організаційні засади реалізації державної політики зайнятості: Мат-ли Всеукр. наук.-практ. конф. 22.12.2015. Львів: Укр. центр соц.-прав. досліджень; Кафедра труд., аграр. та екол. права. Львів. нац. ун-ту ім. Івана Франка. 2016. С. 109-112.

5. Венедиктов С. В. Щодо нестандартних форм зайнятості в Україні. Актуальні питання удосконалення законодавства про прачюю та соціальне забезпечення: Тези доп. та наук. повід. учас. VII Міжнар. наук.-практ. конф. Харків. 29.09.2017. С. 50-54.

6. Вишновецька С. В. До питання про проблеми правового регулювання дистанційної зайнятості працівників. Часопис НаУОА. Серія право. 2015. № 1. С. 1-11. URL: http://er.nau.edu.ua:8080/handle/NAU/18031.

7. Жернаков В. В. Право на зайнятість: проблеми регулювання та реалізації. Правові, економічні та організаційні засади реалізації державної політики зайнятості: Мат-ли Всеукр. наук.-практ. конф. 22.12.2015. Львів: Укр. центр соц.-прав. досліджень; Кафедра труд., аграр. та екол. права. Львів. нац. ун-ту ім. Івана Франка. 2016. С. 61-65.

8. Іншин М. І. Дистанційна зайнятість працівників в умовах ринкової економіки. Форум права. 2014. № 3. C. 466-469. URL: http://nbuv.gov.ua/UJRN/ FP_index.htm_2014_3_79. 
9. Лагутіна І. В. Трудові права позикових працівників. Право і суспільство. 2015. № 5. C. 85-91. URL: http://nbuv.gov.ua/UJRN/Pis_2015_5_17.

10. Пилипенко П. Д. Глобалізація ринку праці та правове забезпечення повної продуктивної і вільно обраної зайнятості. Правові, економічні та організачійні засади реалізаиії державної політики зайнятості: Мат-ли Всеукр. наук.-практ. конф. 22.12.2015. Львів: Укр. центр соц.-прав. досліджень; Кафедра труд., аграр. та екол. права. Львів. нац. унту ім. Івана Франка. 2016. С. 1-7.

11. Прилипко С. М. Правове регулювання зайнятості населення. Проблеми законності : респ. міжвідом. наук. зб. Харків, 2001. Вип. 49. С. 104-113.

12. Процевський О. І. Чи дійсно держава не гарантує громадянам право на працю? $3 б$. наук. пращь Хар. наи. пед. ун-ту імені Г. С. Сковороди «Право». Вип. 20. 2013. С. 10-18.

13. Чанишева Г. І. Правове регулювання неповної зайнятості. Правові, економічні та організаиійні засади реалізації державної політики зайнятості: Мат-ли Всеукр. наук.-практ. конф. 22.12.2015. Львів: Укр. центр соц.-прав. досліджень; Кафедра труд., аграр. та екол. права. Львів. нац. ун-ту ім. Івана Франка. 2016. С. 11-14.

14. Ярошенко О. М. Проблеми та перспективи правового регулювання зайнятості та праці молоді. Вісн. акад. прав. наук України. Х. 2004. № 4. С. 205-213.

15. Логинова Л. В. Прекаризация в системе социально-трудовых отношений: проблемы и перспективы институционализации. Вестник СПбГУ. Сер. 12. Социология. 2016. Вып. 3. C. 34-47.

16. Колот А. М. Трансформация института занятости как составляющая глобальных изменений в социально-трудовой сфере: феномен прекаризации. Уровень жизни населения регионов России. 2013. № 11. С. 93-101.

17. Білик О. М. Нестандартна зайнятість: виклики сьогодення. Соціально-трудові відносини: теорія та практика: зб. наук. пр. К. 2014. № 1. С. 296-301.

18. Messenger J. Three Generations of Telework. Conference Paperforthe 17th ILERA World Congress 7 to 11 Sept. 2015. CapeTown, South Africa. 37 p.

19. Вапнярчук Н. М. Дистанційна зайнятість: проблеми правового регулювання. Право та іннов. 2016. № 1. С. 101-106.

20. Czarzasty J. Teleworkin Poland. Europ. Found. Forthe Improvement of Living and Working Conditions, 2008, Wyattvile Road, Dublin 18, Ireland. Published in English At European Industrial Relations Observatory Online / European Workingconditions Observatory.

21. Проект Трудового кодексу України від 27 грудня 2014 р. (реєстр. № 1658). URL : http://w1.c1.rada.gov.ua/pls/zweb2/webproc4_1?pf3511=53221.

22. Свічкарьова Я. В. Співвідношення телероботи та надомної праці. Вісник Хар. наи. ун-ту ім. В. Н. Каразіна. 2013. № 14. С. 137-141.

23. Міщук М. О. Проблеми правового регулювання укладання трудового договору 3 надомниками. Бюл. Мін. юст. України. 2007. № 4. С. 193-196.

24. Амелічева Л. П. Забезпечення безпеки праці як умови трудового договору: моногр. Донецьк. 2010. 179 с.

25. Кохан В. П. Нестандартна зайнятість в Україні: виклики часу. Право та іннов. суспільство. 2013. Вип. 1. С. 173-187. URL: http://apir.org.ua/wp-content/uploads/2014/11/ kokhan_ua.pdf.

26. Ринок праці та зайнятість населення: проблеми теорії та виклики практики : кол. моногр. / Ред.-коорд. М. В. Туленков. К. 2010. 363 с.

27. Трошина Т. Нетипові форми зайнятості: ризики для працівників та необхідність правового регулювання URL: http://nspplugansk.ucoz.ua/publ/netipovi_formi_zajnjatosti_riziki_ dlja_pracivnikiv_ta_neobkhidnist_pravovogo_reguljuvannja/1-1-0-20.

28. Лагутіна I. В. Нестандартні форми зайнятості та особисті немайнові трудові права працівників. Право і суспільство. 2014. № 5.2. С. 156-161. URI: http://hdl.handle.net/11300/ 2875 .

29. Прилипко С. М., Ярошенко О. М. Трудове право Украӥни: Підруч. Х. 2008. 664 с. 
30. Сыроватская Л. А. Трудовые отношения и трудовое право. Государство и право. 1996. № 7. C. 75-82.

31. Парпан Т. В. Нетипові (нестандартні) види трудової зайнятості: право на існування. Правові, економічні та організаційні засади реалізаиії державної політики зайнятості: Матли Всеукр. наук.-практ. конф. 22.12.2015. Львів: Укр. центр соц.-прав. досліджень; Кафедра труд., аграр. та екол. права. Львів. нац. ун-ту ім. Івана Франка. 2016. С. 114-117.

32. Амелічева Л. П. Деякі проблеми реалізації права на повну та продуктивну зайнятість при впровадженні концепції гідної праці. Правові, економічні та організаційні засади реалізації державної політики зайнятості: Мат-ли Всеукр. наук.-практ. конф. 22.12.2015. Львів: Укр. центр соц.-прав. досліджень; Кафедра труд., аграр. та екол. права. Львів. нац. ун-ту ім. Івана Франка. 2016. С. 19-22.

33. Труба В. І., Потопахіна О. М. Юридична природа трудового договору в умовах ринкової економіки. Правова держава. 2015. № 19. С. 123-128.

34. Сільченко С. О. Строковий трудовий договір : Автореф. дис... канд. юрид. наук : 12.00.05. Нац. юрид. акад. України ім. Я. Мудрого. Х. 2001. 20 с. 